\title{
Kompetensi Pengetahuan Pembina Gerakan Keluarga Sakinah
}

\author{
Iwan Falahudin \\ Balai Diklat Keagamaan Jakarta \\ E-mail: iwanaja1011@gmail.com
}

\begin{abstract}
This study aims to determine the differences in knowledge competencies of the participants of the Diklat Pembina Keluarga Sakinah before and after learning. The research was conducted at BDK Jakarta on Monday - Saturday, 11-16 November 2019. This research approach is quantitative with the ex post facto method. Data were collected through pre-test and post-test using multiple choice questions. The study population was the participants of three classes training totaling 120 participants. The data were processed using descriptive statistics by comparing the pre-test and post-test scores. The results showed that there had been a significant increase in the knowledge competence of the training participants. It is recommended that the relevant training should be continued with a larger number of generations.
\end{abstract}

Key words: retention, Sakinah Family Counselor, training

\begin{abstract}
Abstrak
Penelitian ini bertujuan untuk mengetahui perbedaan kompetensi pengetahuan para peserta diklat pembina keluarga sakinah sebelum dan sesudah pembelajaran. Penelitian dilaksanakan di BDK Jakarta pada hari Senin - Sabtu, Tanggal 11 - 16 November 2019. Pendektan penelitian ini adalah kuantitatif dengan metode ex post facto. Data dikumpulkan melalui pre tes dan post tes menggunakan soal pilihan ganda. Populasi penelitian adalah para peserta Diklat Teknis Substantif Keluarga Sakinah dengan sampel 3 angkatan berjumlah 120 peserta. Data diolah menggunakan statistic deskriptif dengan cara membandingkan skor pre tes dan pos tes. Hasil penelitian menunjukkan bahwa telah terjadi peningkatan kompetensi pengetahuan pada peserta diklat secara signifikan. Direkomendasikan bahwa diklat bersangkutan harus dilanjutkan dengan jumlah angkatan yang lebih bnayak.
\end{abstract}

Kata kunci: Diklat, kompetensi pengetahuan, Pembina Keluarga Sakinah.

\section{PENDAHULUAN}

Masalah umum dalam sebuah perkawinan adalah berbedanya antara harapan dan kenyataan dalam kehidupan berumah tangga. Harapan hidup berumah tangga adalah dapat menyatukan, atau setidaknya menyelaraskan visi, misi, budaya, dan pola pikir yang berbeda, agar memiliki kehidupan yang aman, nyaman, damai, tenteram dan bahagia lahir batin hingga akhir hayat, namun fakta ada ternyata tidak selalu seperti yang diharapkan.

Ditemukan banyak konflik dalam kehidupan berumah tangga, bahkan hingga dapat mengarah dan berakibat pada perceraian.

Dalam rangka mengantisipasi, meredam dan mengendalikan serta 
meminimalkan potensi konflik dalam rumah tangga, kementerian agama meluncurkan sebuah program yang diharapkan dapat menjadi solusi alternatif, atau salah satu jalan keluar yang bisa menjadi pegangan bangsa Indonesia khususnya umat Islam, baik yang belum menikah maupun yang sudah menikah. Program tersebut bernama pembinaan gerakan keluarga sakinah (KMA Nomor 3 Tahun 1999).

Untuk menjalankan kebijakan kementerian agama tentang pembinaan gerakan keluarga sakinah, maka Balai Diklat Keagamaan/BDK Jakarta mengadakan pendidikan dan pelatihan bagi pembina gerakan keluarga sakinah. Sasaran utamanya adalah pembina gerakan keluarga sakinah utusan dari beberapa kecamatan di wilayah kerja BDK Jakarta.

Asumsinya jika kompetensi pengetahuan para pembina gerakan keluarga sakinah itu meningkat, maka kemampuan mereka dalam melakukan bimbingan dan penyuluhannya pun diharapkan menjadi lebih optimal. Dan diharapkan pula hasil bimbingan dan penyuluhan tentang keluarga sakinah kepada masyarakat umum itu menjadi meningkat pula. Dan out come nya adalah menurunnya atau terkendalinya tingkat konflik dalam rumah tangga.

Masalah utama dalam penelitian ini adalah harapan optimalisasi kompetensi pengetahuan para pembina gerakan keluarga sakinah, namun faktanya belum mencapai target sebagaimana yang diharapkan. Maka rumusan masalahnya adalah: Bagaimana tingkat kompetensi pengetahuan para pembina gerakan keluarga sakinah sebelum dan sesudah mengikuti pembelajaran dalam diklat?
Tujuan penelitian ini adalah untuk mengetahui perbedaan kompetensi substantif para peserta diklat pembina keluarga sakinah, sebelum dan sesudah mengikuti pembelajaran dalam diklat.

Manfaat penelitian ini secara umum adalah memotivasi para pembaca untuk mempraktikkan konsep belajar seumur hidup. Sedangkan manfaat khususnya adalah memotivasi pembaca untuk meng-upgrade pengetahuan tentang keluarga sakinah.

Secara umum program pembinaan gerakan keluarga sakinah itu memang bukan merupakan jaminan tunggal untuk menghilangkan konflik rumah tangga, tapi setidaknya diharapkan dapat mengurangi intensitas dan bobot konflik sebagai salah satu out come-nya (Kepdirjen Bimas Islam \& Urusan Haji, No. 71 Tahun 1999).

Program pembinaan gerakan Keluarga sakinah sebagaimana yang dicanangkan kementerian agama ini bukanlah berarti keluarga yang tanpa konflik. Dalam sebuah interaksi, konflik adalah suatu keniscayaan. Misalnya dapat berasal pendapat yang berbeda, keinginan yang tidak sama, persoalan hidup yang datang silih berganti, baik dari aspek sosial, ekonomi, budaya, ataupun yang lainnya. Fokus dari program ini adalah bagaimana sebuah keluarga dapat menghadapi, mengelola, atau menyelesaikan masalah dalam kehidupan rumah tangganya dengan baik (Juknis Pembinaan Gerakan Keluarga Sakinah, 2011).

Pembina keluarga sakinah yang dimaksud dalam konteks penulisan ini dibatasi pada para penghulu dan penyuluh agama Islam. Mereka bertugas di kantor urusan agama (KUA) yang ada di hampir setiap kecamatan di Indonesia. 
Secara umum, kompetensi yang harus dimiliki para penghulu ada tiga macam, yaitu kompetensi manajerial, kompetensi teknis, dan dan kompetensi sosial.

Kompetensi penghulu yang sesuai dengan konteks penulisan ini adalah kompetensi teknis. Kompetensi teknis adalah kompetensi yang diukur dari tingkat dan spesialisasi pendidikan, pelatihan teknis fungsional, dan pengalaman bekerja secara teknis, kemampuan melakukan sosialisasi, kemampuan dalam membaca Alquran dan maknanya, kemampuan membaca kitab kuning, khususnya yang berkaitan dengan Fiqh Munakahat dan permasalahan munakahat kontemporer serta kemampuan berkomunikasi dengan menggunakan bahasa Arab dan atau Inggris.

Termasuk ke dalam kompetensi teknis penghulu adalah melakukan perencanaan kegiatan kepenghuluan, pengawasan pencatatan nikah/rujuk, pelaksanaan pelayanan nikah rujuk, penasihatan dan konsultasi nikah/ rujuk, pemantauan pelanggaran ketentuan nikah/rujuk, pelayanan fatwa hukum munakahat dan bimbingan muamalah, pembinaan keluarga sakinah, serta pemantauan dan evaluasi kegiatan kepenghuluan dan pengembangan kepenghuluan.

Salah satu tugas pokok penghulu sebagaimana tersebut di atas adalah pembinaan keluarga sakinah. Maka dalam rangka meningkatkan kompetensi teknis dan menjalankan kebijakan kementerian agama itu, diadakanlah diklat teknis substantif pembina gerakan keluarga sakinah, sesuai dengan statusnya sebagai aparatur sipil negara yang berkewajiban untuk meningkat- kan kompetensinya (Kepdirjen Bimas Islam Nomor DJ. II/102 Tahun 2016).

Tugas pokok penyuluh agama adalah melakukan bimbingan dan penyuluhan agama serta pembangunan melalui bahasa agama. Secara khusus untuk penyuluh agama Islam adalah melakukan bimbingan dalam aspek baca tulis Alquran, keluarga sakinah, zakat, wakaf, produk halal kerukunan umat beragama, anti radikalisme dan aliran sempalan, anti napza (narkoba, alkohol, psikotropika, dan zat adiktif), dan HIV/ AIDS (Human Immunodeficiency Virus/ Acquired Immuno Deficiency Syndrome). Ke 8 poin tugas itu sekaligus menjadi spesialisasi penyuluh agama Islam (Kepdirjen Bimas Islam Nomor 298 Tahun 2017).

Jika kompetensi substantif para pembina gerakan keluarga sakinah itu meningkat, maka kemampuan mereka dalam melakukan bimbingan dan penyuluhan pun diharapkan menjadi lebih optimal. Hasil bimbingan dan penyuluhan tentang keluarga sakinah kepada masyarakat umum pun menjadi meningkat pula.

Selanjutnya outcome yang diharapkan adalah menurunnya atau terkendalinya tingkat konflik dalam rumah tangga.

1. Program Gerakan Pembinaan Keluarga Sakinah Kementerian Agama

2. Diklat Pembina

Gerakan Keluarga Sakinah

3. Kompetensi Substantif Pembina

Gerakan Keluarga Sakinah Meningkat 


\section{Bimbingan \& Penyuluhan Tentang}

Keluarga Sakinah Kepada Masyarakat Semakin Berkualitas

\section{Terkendalinya Tingkat Konflik}

Rumah Tangga

Balai Diklat Keagamaan / BDK Jakarta memiliki tiga jenis kediklatan, yaitu: 1) Diklat dministrasi (untuk para calon pegawai negeri sipil, manajemen pegawai, dan pimpinan kepegawaian), 2) Diklat teknis pendidikan (untuk para tenaga pendidik dan kependidikan), dan 3) Diklat teknis keagamaan (untuk penghulu dan penyuluh dari barbagai agama).

Dalam konteks tulisan ini, para pesertanya adalah penghulu dan penyuluh agama Islam yang menjadi pembina gerakan keluarga sakinah di masingmasing kecamatan tempatnya bertugas.

Masalah-masalah yang sering ditemukan dalam diklat teknis keagamaan diantaranya adalah: 1) Belum sinkronnya antara waktu undangan untuk mengikuti diklat dan penerimaan informasi bagi para calon peserta diklat. 2) Belum meratanya kuota keikutsertaan diklat. 3) Belum maksimalnya kompetensi pengetahuan para pembina keagamaan, dan lain-lain.

Tulisan ini membahas aspek nomor 3 sebagaimana tersebut di atas. Maka membuktikan asumsi masalah itu penelitian ini dilakukan dengan cara melihat hasil pre dan post test para peserta diklat. Penelitian dimaksudkan untuk menjawab pertanyaan berikut: Apakah terjadi peningkatan kompetensi pengetahuan pada para peserta diklat setelah mengikuti Diklat Keluarga Skinah?

\section{METODOLOGI}

Penilitian ini bersifat kuanitatif deskriptif dengan metode ex pos facto. Data hasil Diklat dalam bentuk pre dan post test diambil dari dokumen laporan Diklat Teknis Substantif Pembina Keluarga Sakinah yang diselenggarakan pada selama 6 hari, tanggal 11-16 November 2019. Populasi penelitian adalah seluruh peserta diklat pembina gerakan keluarga sakinah yang terdiri atas dua profesi yaitu, penghulu, dan penyuluh agama Islam, baik PNS maupun Non-PNS. Sampel penelitian adalah tiga Angkatan diklat pembina gerakan keluarga sakinah, berjumlah 120 orang. Para peserta Diklat ini berasal dari Kotamadya Jakarta Barat, Jakarta Utara, dan Jakarta Timur.

Data dianalisis dengan cara membandingkan rata-rata hasil pre dan post test menggunakan statistik deskriptif. Penelitian dilaksanakan di Balai Diklat Keagamaan Jakarta pada bulan November 2019, dan penyusunan laporan penelitian dilakukan pada Juli Agustus 2020.

Tahap awal pengujian dengan cara melakukan pre test (tes yang dilakukan sebelum pembelajaran materi kediklatan dilaksanakan). Tahap kedua dilakukan pengujian post test (tes yang dilakukan sesudah pembelajaran materi kediklatan dilaksa-nakan). Post tes itu juga dilakukan kepada tiga angkatan peserta diklat 'Pembina Keluarga Sakinah' sebagai-mana tersebut pada hari kelima pelaksanaan diklat.

Pelaksanaan test dilakukan secara klasikal di Balai Diklat Keagamaan Jakarta. Kriteria nilai minimal yang 
ditentukan bagi peserta diklat adalah 76. Artinya nilai 75 ke bawah berarti tidak lulus. Mengacu pada ketentuan yang biasa diberlakukan.

Ada enam dokumen nilai hasil pre dan posttest yang digunakan sebagai acuan peneliti untuk mengetahui ada atau tidaknya peningkatan hasil belajar para peserta diklat.

Pertama, adalah tiga dokumen hasil nilai pretest yang tergambar dalam tabel berikut:

Tabel 1, Nilai Hasil Pretest Peserta Diklat Pembina Keluarga Sakinah Angkatan 1, Kota Madya Jakarta Barat, 12 November 2019.

\begin{tabular}{|l|l|l|l|l|}
\hline \multirow{2}{*}{$\begin{array}{l}\mathrm{N} \\
\mathrm{o}\end{array}$} & \multicolumn{2}{|c|}{ Nilai } & $\begin{array}{l}\text { Jumla } \\
\text { h } \\
\text { Pesert } \\
\text { a } \\
\text { Diklat }\end{array}$ & Predika \\
\hline 1 & $90-100$ & $\begin{array}{l}\text { Sangat } \\
\text { Baik }\end{array}$ & - & - \\
\hline 2 & $80-89$ & Baik & 4 & $10 \%$ \\
\hline 3 & $76-79$ & Cukup & 10 & $25 \%$ \\
\hline 4 & $00-75$ & $\begin{array}{l}\text { Tidak } \\
\text { Lulus }\end{array}$ & 26 & $65 \%$ \\
\hline 5 & Jumlah & & $\begin{array}{l}40 \\
\text { Orang }\end{array}$ & $\begin{array}{l}100 \\
\%\end{array}$ \\
\hline
\end{tabular}

Dari data di atas dapat dapat dideskripsikan bahwa sesuai dengan kriteria nilai terendah yang telah ditetapkan: 4 orang peserta diklat telah tuntas pembelajarannya dengan kriteria baik, atau sebanyak $10 \%$. Dan 10 orang peserta diklat telah tuntas pembelajarannya dengan kriteria cukup, atau sebanyak $25 \%$.

Jadi jumlah peserta diklat yang telah tuntas pembelajarannya dengan kriteria baik dan cukup sebanyak 14 orang, atau $35 \%$.
Peserta diklat yang belum tuntas pembelajarannya sebanyak 26 orang, atau $65 \%$. Cukup jauh dari standar yang diharapkan dalam sebuah pembelajaran secara umum.

Selanjutnya nilai hasil pre test para peserta diklat Jakarta Utara:

Tabel 2, Nilai Hasil Pre Test Peserta

Diklat Pembina Keluarga Sakinah Angkatan 2, Kota Madya Jakarta Utara, 12 November 2019.

\begin{tabular}{|c|c|c|c|c|}
\hline $\mathrm{N}$ & & Tilai & Jumlah & $\%$ \\
\hline o & Angka & Predikat & $\begin{array}{l}\text { Peserta } \\
\text { Diklat }\end{array}$ & \\
\hline 1 & $\begin{array}{l}90- \\
100\end{array}$ & $\begin{array}{l}\text { Sangat } \\
\text { Baik }\end{array}$ & - & - \\
\hline 2 & $80-89$ & Baik & 6 & $15 \%$ \\
\hline 3 & $76-79$ & Cukup & 10 & $25 \%$ \\
\hline 4 & $00-75$ & $\begin{array}{l}\text { Tidak } \\
\text { Lulus }\end{array}$ & 24 & $60 \%$ \\
\hline 5 & Jumlah & & $\begin{array}{l}40 \\
\text { Orang }\end{array}$ & $100 \%$ \\
\hline
\end{tabular}

Dari data di atas dapat dapat dideskripsikan bahwa sesuai dengan kriteria nilai terendah yang telah ditetapkan: 6 orang peserta diklat telah tuntas pembelajarannya dengan kriteria baik, atau sebanyak $15 \%$. Dan 10 orang peserta diklat telah tuntas pembelajarannya dengan kriteria cukup, atau sebanyak $25 \%$.

Jadi jumlah peserta diklat yang telah tuntas pembelajarannya dengan kriteria baik dan cukup sebanyak 16 orang, atau $40 \%$.

Peserta diklat yang belum tuntas pembelajarannya sebanyak 24 orang, atau $60 \%$. Masih cukup jauh dari standar yang diharapkan dalam sebuah pembelajaran.

Selanjutnya nilai hasil pre test para peserta diklat Jakarta Timur: 
Tabel 3, Nilai Hasil Pre Test Peserta

Diklat Pembina Keluarga Sakinah Angkatan 3, Kota Madya Jakarta Timur, 12 November 2019.

\begin{tabular}{|c|c|c|c|c|}
\hline \multirow{2}{*}{$\begin{array}{l}\mathrm{N} \\
\mathrm{O}\end{array}$} & \multicolumn{2}{|c|}{ Nilai } & \multirow{2}{*}{$\begin{array}{l}\text { Jumla } \\
\text { h } \\
\text { Pesert } \\
\text { a } \\
\text { Diklat }\end{array}$} & \multirow[t]{2}{*}{$\%$} \\
\hline & $\begin{array}{l}\text { Angk } \\
\text { a }\end{array}$ & $\begin{array}{l}\text { Predik } \\
\text { at }\end{array}$ & & \\
\hline 1 & $\begin{array}{l}90- \\
100\end{array}$ & $\begin{array}{l}\text { Sangat } \\
\text { Baik }\end{array}$ & - & - \\
\hline 2 & $\begin{array}{l}80- \\
89\end{array}$ & Baik & 8 & $20 \%$ \\
\hline 3 & $\begin{array}{l}76- \\
79\end{array}$ & Cukup & 12 & $30 \%$ \\
\hline 4 & $\begin{array}{l}00- \\
75\end{array}$ & $\begin{array}{l}\text { Tidak } \\
\text { Lulus }\end{array}$ & 20 & $50 \%$ \\
\hline 5 & Jumlah & & $\begin{array}{l}40 \\
\text { Orang }\end{array}$ & $\begin{array}{l}100 \\
\%\end{array}$ \\
\hline
\end{tabular}

Dari data di atas dapat dapat dideskripsikan bahwa sesuai dengan kriteria nilai terendah yang telah ditetapkan: 8 orang peserta diklat telah tuntas pembelajarannya dengan kriteria baik, atau sebanyak $20 \%$. Dan 12 orang peserta diklat telah tuntas pembelajarannya dengan kriteria cukup, atau sebanyak $30 \%$.

Jadi jumlah peserta diklat yang telah tuntas pembelajarannya dengan kriteria baik dan cukup sebanyak 20 orang, atau $50 \%$.

Peserta diklat yang belum tuntas pembelajarannya sebanyak 20 orang, atau 50\%. Masih cukup jauh dari standar yang diharapkan dalam sebuah pembelajaran.

Selanjutnya nilai hasil post test para peserta diklat Jakarta Barat:

Tabel 4, Nilai Hasil Post Test Peserta Diklat Pembina Keluarga Sakinah Angkatan 1, Kota Madya Jakarta Barat, 15 November 2019.

\begin{tabular}{l|l|l} 
Nilai & Jumlah & $\%$
\end{tabular}

\begin{tabular}{|l|l|l|c|c|}
\hline $\begin{array}{l}\text { N } \\
\text { o }\end{array}$ & Angka & Predikat & $\begin{array}{c}\text { Peserta } \\
\text { Diklat }\end{array}$ & \\
\hline 1 & $\begin{array}{l}90- \\
100\end{array}$ & $\begin{array}{l}\text { Sangat } \\
\text { Baik }\end{array}$ & 4 & $10 \%$ \\
\hline 2 & $80-89$ & Baik & 8 & $20 \%$ \\
\hline 3 & $76-79$ & Cukup & 28 & $70 \%$ \\
\hline 4 & $00-75$ & $\begin{array}{l}\text { Tidak } \\
\text { Lulus }\end{array}$ & - & - \\
\hline 5 & Jumlah & $\begin{array}{l}40 \\
\text { Orang }\end{array}$ & $100 \%$ \\
\hline
\end{tabular}

Dari data di atas dapat dapat dideskripsikan bahwa sesuai dengan kriteria nilai terendah yang telah ditetapkan: 4 orang peserta diklat telah tuntas pembelajarannya dengan kriteria sangat baik, atau sebanyak $10 \%$. Dan 8 orang peserta diklat telah tuntas pembelajarannya dengan kriteria baik, atau sebanyak $20 \%$.

Jadi jumlah peserta diklat yang telah tuntas pembelajarannya dengan kriteria sangat baik dan baik sebanyak 12 orang, atau $30 \%$.

Peserta diklat yang sudah tuntas pembelajarannya dengan kriteria cukup sebanyak 28 orang, atau $70 \%$. Cukup memadai dari standar yang diharapkan dalam sebuah pembelajaran.

Selanjutnya nilai hasil post test para peserta diklat Jakarta Utara:

Tabel 5, Nilai Hasil Post Test Peserta

Diklat Pembina Keluarga Sakinah Angkatan 2, Kota Madya Jakarta Utara, 15 November 2019.

\begin{tabular}{|l|l|l|l|l|}
\hline N & \multicolumn{2}{|c|}{ Nilai } & Jumla & $\%$ \\
\cline { 2 - 5 } o & Angka & $\begin{array}{l}\text { Predik } \\
\text { at }\end{array}$ & $\begin{array}{l}\text { Pesert } \\
\text { Pe } \\
\text { Diklat }\end{array}$ & \\
\hline 1 & $\begin{array}{l}90- \\
100\end{array}$ & $\begin{array}{l}\text { Sangat } \\
\text { Baik }\end{array}$ & 2 & $5 \%$ \\
\hline 2 & $80-89$ & Baik & 10 & $25 \%$ \\
\hline
\end{tabular}




\begin{tabular}{|l|l|l|c|l|}
\hline 3 & $76-79$ & Cukup & 28 & $70 \%$ \\
\hline 4 & $00-75$ & $\begin{array}{l}\text { Tidak } \\
\text { Lulus }\end{array}$ & - & - \\
\hline 5 & Jumlah & $\begin{array}{l}40 \\
\text { Orang }\end{array}$ & $100 \%$ \\
\hline
\end{tabular}

Dari data di atas dapat dapat dideskripsikan bahwa sesuai dengan kriteria nilai terendah yang telah ditetapkan: 2 orang peserta diklat telah tuntas pembelajarannya dengan kriteria sangat baik, atau sebanyak $5 \%$. Dan 10 orang peserta diklat telah tuntas pembelajarannya dengan kriteria baik, atau sebanyak $25 \%$.

Jadi jumlah peserta diklat telah tuntas pembelajarannya dengan kriteria sangat baik dan baik sebanyak 12 orang, atau $30 \%$.

Peserta diklat yang sudah tuntas pembelajarannya dengan kriteria cukup sebanyak 28 orang, atau 70\%. Sudah cukup memadai dari standar yang diharapkan dalam pembelajaran.

Selanjutnya nilai hasil post test para peserta diklat Jakarta Timur:

Tabel 6, Nilai Hasil Post Test Peserta

Diklat Pembina Keluarga Sakinah Angkatan 3, Kota Madya Jakarta Timur, 15 November 2019.

\begin{tabular}{|l|l|l|c|c|}
\hline N & \multicolumn{2}{|c|}{ Nilai } & Jumlah & $\%$ \\
\cline { 2 - 5 } o & $\begin{array}{l}\text { Angk } \\
\text { a }\end{array}$ & $\begin{array}{l}\text { Predika } \\
\mathrm{t}\end{array}$ & $\begin{array}{l}\text { Peserta } \\
\text { Diklat }\end{array}$ & \\
\hline 1 & $\begin{array}{l}90- \\
100\end{array}$ & $\begin{array}{l}\text { Sangat } \\
\text { Baik }\end{array}$ & 6 & $15 \%$ \\
\hline 2 & $\begin{array}{l}80- \\
89\end{array}$ & Baik & 12 & $30 \%$ \\
\hline 3 & $\begin{array}{l}76- \\
79\end{array}$ & Cukup & 22 & $55 \%$ \\
\hline 4 & $\begin{array}{l}00- \\
75\end{array}$ & $\begin{array}{l}\text { Tidak } \\
\text { Lulus }\end{array}$ & - & - \\
\hline 5 & Jumlah & & $\begin{array}{l}40 \\
\text { Orang }\end{array}$ & $100 \%$ \\
\hline
\end{tabular}

Dari data di atas dapat dapat dideskripsikan bahwa sesuai dengan kriteria nilai terendah yang telah ditetapkan: 6 orang peserta diklat telah tuntas pembelajarannya dengan kriteria sangat baik, atau sebanyak $15 \%$. Dan 12 orang peserta diklat telah tuntas pembelajarannya dengan kriteria baik, atau sebanyak $30 \%$.

Jadi jumlah peserta diklat yang telah tuntas pembelajarannya dengan kriteria baik dan cukup sebanyak 18 orang, atau $45 \%$.

Peserta diklat yang sudah tuntas pembelajarannya dengan kriteria cukup sebanyak 22 orang, atau 55\%. Sudah cukup memadai dari standar yang diharapkan dalam pembelajaran.

Penyebab rendahnya nilai hasil tes peserta diklat 'Pembina Keluarga Sakinah' adalah faktor belum maksimalnya sosialisasi dan juga diseminasi materi konsep keluarga sakinah di kalangan kepada para pembina gerakan keluarga khususnya, dan masyarakat pada umumnya.

Terbukti ketika diberikan materi konsep keluarga sakinah pada 3 angkatan diklat, dan dilakukan pre dan post test, maka kompetensi substantif peserta diklat mengalami peningkatan. Hal ini dapat terlihat dari dokumen yang ada, bahwa nilai hasil ujian berupa post test lebih tinggi dari hasil ujian berupa pre test.

\section{KESIMPULAN DAN REKOMEN- DASI}

\section{Kesimpulan}

Berdasarkan uraian yang telah penulis deskripsikan pada bagian sebelumnya, dapat diketahui bahwa hasil ujian post test peserta diklat pembina keluarga sakinah ternyata lebih tinggi dari pada hasil ujian pada tahap pre test. 
Bahkan tingkat kelulusan yang semula hanya 35\% (Jakarta Barat), 40\% (Jakarta Utara), dan 50\% (Jakarta Timur) menjadi $100 \%$ lulus untuk semua angkatan.

Maka kesimpulannya adalah bahwa diseminasi dan atau sosialisasi kebijakan pemerintah dalam hal ini adalah kementerian agama melalui proses pembelajaran dalam forum diklat di Balai Diklat Keagamaan Jakarta, telah dapat meningkatkan kompetensi substantif peserta diklat keluarga sakinah secara signifikan.

\section{Rekomendasi}

a. Bagi widyaiswara/Nara Sumber Hendaknya dapat lebih meningkat-kan kompetensinya dalam rangka memfasilitasi pembelajaran bagi para peserta diklat.

\section{b. Bagi Peserta Diklat}

Hendaknya dapat lebih aktif belajar melalui berbagai sumber belajar, misalnya kepada kawan, widyaiswa-ra dan atau kepada sumber belajar lainnya.

\section{c. Bagi Instansi}

Hendaknya dapat lebih memfasilitasi widyaiswara dan peserta diklat dengan menambah program kuota diklat keluarga sakinah.

\section{DAFTAR PUSTAKA}

\section{Keputusan Direktorat Jenderal Bimbingan masyarakat Islam/ Kepdirjen Bimas Islam, \& Urusan Haji, No. 71 Tahun 1999, Tentang Petunjuk Pelaksanaan Pembinaan Gerakan Keluarga Sakinah, Softcopy.}

\begin{tabular}{lcc}
\multicolumn{2}{c}{ Keputusan Direktorat } & Jenderal \\
Bimbingan masyarakat & Islam/ \\
Kepdirjen Bimas Islam, & Nomor
\end{tabular}

DJ.II/102 Tahun 2016, Tentang Kompetensi Penghulu, Softcopy.

Keputusan Direktorat Jenderal Bimbingan masyarakat Islam/ Kepdirjen Bimas Islam, Nomor 298 Tahun 2017, Tentang Pedoman Penyuluh Agama Islam Non Pegawai Negeri Sipil, Softcopy.

Keputusan Menteri Agama Republik Indonesia Nomor 3 Tahun 1999 Tentang Pembinaan Gerakan Keluarga Sakinah, softcopy. 